\title{
PERBEDAAN HASIL BELAJAR MATEMATIKA MELALUI METODE TEAM ASSISTED INDIVIDUALIZATION DAN METODE DRILL
}

\author{
Bayu Jaya Tama \\ Program Studi Teknik Informatika, Universitas Indraprasta PGRI \\ Email: Bayujaya88@gmail.com
}

\begin{abstract}
Abstrak
Penelitian ini bertujuan untuk mengetahui ada atau tidak adanya perbedaan hasil belajar matematika siswa dengan model pembelajaran kooperatif metode Team Assisted Individualization dan metode drill. Penelitian ini dilaksanakan pada salah satu SMA Negeri di Jakarta. Sampel diambil secara acak sederhana (simple random sampling) dengan mengambil sebanyak 60 siswa dari populasi sebanyak 80 siswa yang terdiri dari 2 kelas. Metode eksperimen ini untuk membedakan 2 kelompok yang diteliti yaitu kelompok eksperimen diberikan pembelajaran kooperatif metode Team Assisted Individualization dan kelompok kontrol diberikan metode drill. Instrumen penelitian berupa soal pilihan ganda sebanyak 40 butir soal. Instrumen diuji cobakan untuk mendapatkan butir soal yang valid dan reliabel yang akan digunakan untuk instrumen penelitian. Dari uji validitas hasil belajar matematika siswa dengan rumus point Biserial Correlation didapat 24 butir soal yang valid dan reliabel. Sebelum data dianalisis terlebih dahulu dilakukan uji prasyaratan yaitu uji normalitas menggunakan uji lilliefors dan uji homogenitas menggunakan uji fisher. Hasil penelitian menunjukan bahwa terdapat perbedaan hasil belajar matematika siswa dengan model pembelajaran kooperatif metode Team Assisted Individualization dan metode drill pada SMA Negeri di Jakarta.
\end{abstract}

Kata kunci: pembelajaran kooperatif, Team Assisted Individualization, drill

\begin{abstract}
This research aims to know whether there is a difference between the mathematics learning results of students taught with a cooperative learning method Team Assisted Individualization and those taught with a drill method. The research is conducted in one of State Senior High Schools in Jakarta. The samples are 60 students randomly taken (simple random sampling) from the population of 80 students from 2 classes. The experimental method is used to distinguish two researched groups, namely an experimental group taught with a cooperative learning method Team Assisted Individualization and a control group taught with a drill method. The research instrument is in the form of 40 multiple-choice questions. The instrument is tested to obtain valid and reliable questions to be used for the research instrument. The validity test on the results of students' mathematics learning with point biserial Correlation formula shows as many as 24 questions are valid and reliable. Before being analyzed, the data are first tested using a pre-requisite test, namely a normality test using lilliefors test and homogeneity test using fisher test. The result of the research shows a difference between the mathematics learning results of students taught with a cooperative learning method Team Assisted Individualization and those taught with a drill method in the State Senior High School in Jakarta.
\end{abstract}

Keywords: cooperative learning, Team Assisted Individualization, drill

\section{Pendahuluan}

Pendidikan adalah wahana perubahan tingkah laku manusia, baik formal, nonformal, maupun informal. Jika tujuan pendidikan nasional ingin dicapai dengan maksimal, maka seluruh lembaga pendidikan yang ada harus dapat mengoptimalkan fungsi mereka sebagai agent of change sekaligus pembimbing bagi pendidikan moral siswa. Pendidikan sangat penting, sebagaimana tercantum dengan jelas dalam Undang-Undang Sistem Pendidikan Nasional (Depdiknas, 2013: 5), yakni Nomor 20 tahun 2003 pasal 3 Pendidikan Nasional berfungsi mengembangkan kemampuan dan membentuk watak serta peradaban bangsa yang 
bermartabat dalam rangka mencerdaskan kehidupan bangsa, bertujuan untuk berkembangnya potensi siswa agar menjadi manusia yang beriman dan bertaqwa kepada Tuhan Yang Maha Esa, berakhlaq mulia, sehat, berilmu, cakap, kreatif, mandiri, dan menjadi warga negara yang demokratis serta bertanggung jawab.

Matematika merupakan ilmu yang mempunyai peranan yang sangat penting dalam kehidupan sehari-hari serta dalam kemajuan ilmu pengetahuan dan teknologi pada umumnya. Matematika merupakan salah satu mata pelajaran pokok di sekolah baik di sekolah dasar, sekolah menengah sampai dengan perguruan tinggi. Oleh karena itu, matematika perlu dipelajari oleh siswa karena matematika merupakan sarana berpikir untuk menumbuh kembangkan pola berpikir logis, sistematis, objektif, kritis dan rasional.

Usaha perbaikan dan peningkatan kualitas pendidikan di Indonesia telah lama dilakukan, termasuk kualitas pendidikan matematika di sekolah. Namun usaha tersebut belum menunjukkan hasil yang memuaskan. Dalam proses belajar mengajar, setiap guru selalu berusaha agar hasil belajar siswa tidak rendah. Untuk itu diperlukan metode pengajaran yang tepat. Metode drill dalam belajar matematika sudah tidak asing bagi pembelajaran di sekolah. Metode drill dinilai cukup efektif dan efisien karena dalam belajar matematika siswa harus banyak berlatih untuk mengerjakan tugas yang berupa soal-soal yang berkaitan dengan matematika agar siswa menjadi lebih terampil dan terbiasa jika dihadapi dengan soal-soal yang berkaitan dengan matematika. Namun, karena terlalu seringnya guru memberikan latihan akan menimbulkan kejenuhan dan siswa menganggap bahwa matematika itu membosankan.

Untuk mengatasi permasalahan tersebut, tentunya dibutuhkan metode yang beraneka ragam sehingga tidak membosankan dan metode yang digunakan sangat familiar terhadap lingkungan siswa. Salah satu metode yang bisa digunakan adalah metode Team Assisted Individualization, jika dibandingkan dengan tipe yang lain dari model pembelajaran kooperatif maka metode Team Assisted Individualization adalah suatu model pembelajaran kooperatif yang sederhana. Hanya dalam hal ini, model pembelajaran kooperatif metode Team Assisted Individualization dalam kegiatan kelompoknya menggunakan aturan-aturan tertentu. Misalnya siswa dalam satu kelompok harus heterogen, baik dalam kemampuan maupun jenis kelamin atau etnis, siswa yang menguasai bahan pelajaran lebih dulu harus membantu teman kelompoknya yang belum menguasai pelajaran. Meskipun tetap menggunakan pola kooperatif, tipe ini lebih menekankan pengajaran individual. Kompetensi yang harus dikuasai oleh siswa lebih ditekankan pada kompetensi individual meskipun dilakukan dalam bentuk diskusi kelompok.

Model pembelajaran kooperatif metode Team Assisted Individualization merupakan bentuk model pembelajaran yang dapat melatih siswa berpikir kreatif, kritis, dan efektif. Selain itu, metode Team Assisted Individualization dibuat untuk memanfaatkan keuntungan potensi siswa dalam bersosialisasi yang baik dari model pembelajaran kooperatif. Dengan menerapkan model pembelajaran kooperatif metode Team Assisted Individualization para siswa diharapkan akan termotivasi dalam pelajaran matematika, siswa akan saling mengecek pekerjaan satu sama lain. Apabila ada salah satu anggota kelompok yang tidak paham, maka dapat bertanya kepada anggota lainnya yang paham. Namun apabila seluruh anggota kelompok tidak ada yang paham maka baru bertanya kepada guru. Siswa tidak akan merasa bodoh atau kalah dengan teman lainnya, karena masing-masing anggota kelompok bertanggung jawab terhadap keberhasilan anggota kelompok lainnya. Berdasarkan karakeristik belajar metode Team Assisted Individualization tersebut pada akhirnya diharapkan dapat meningkatkan pemahaman siswa terhadap pembelajaran matematika serta dapat meningkatkan motivasi siswa agar dapat berprestasi di dalam pelajaran matematika. 
Tujuan penelitian ini adalah untuk mengetahui:

1. Apakah ada perbedaan hasil belajar matematika siswa dengan model pembelajaran kooperatif metode Team Assisted Individualization dan metode drill.

2. Penelitian ini juga bertujuan untuk meningkatkan pemahaman siswa pada pokok bahasan turunan.

Penelitian ini bermanfaat bagi guru sebagai wacana dalam menerapkan metode pengajaran dan dalam pemilihan metode yang tepat untuk meningkatkan hasil belajar matematika siswa. Sebagai referensi bagi mahasiswa dan pihak-pihak lain yang berminat untuk mengadakan penelitian lebih tentang model pembelajaran kooperatif metode Team Assisted Individualization.

\section{Tinjauan Pustaka}

Seseorang dikatakan belajar bila diasumsikan dalam diri orang itu terjadi suatu proses kegiatan yang mengakibatkan perubahan tingkah laku. Belajar dianggap sebagai proses perubahan perilaku sebagai akibat dari pengalaman dan latihan. Hilgard mengemukakan dalam bukunya yang telah dikutip oleh Sanjaya (2005: 89) bahwa "Learning is the process by which an activity originates or changed through training procedures (whether in the laboratory or in the natural environment) as distinguished from changes by factors not attributable to training". Bagi Hilgard, belajar adalah proses perubahan melalui kegiatan atau prosedur latihan baik latihan di dalam laboratorium maupun dalam lingkungan alamiah. Jadi, belajar bukanlah sekedar mengumpulkan pengetahuan saja.

Menurut Travers (dalam Suprijono, 2009: 2), belajar adalah proses menghasilkan penyesuaian tingkah laku. Menurut Slameto (2003a: 3) belajar ialah suatu proses usaha yang dilakukan seseorang untuk memperoleh suatu perubahan tingkah laku yang baru secara keseluruhan, sebagai hasil pengalamannya sendiri dalam interaksi dengan lingkungannya. Perubahan yang terjadi dalam diri seseorang banyak sekali, baik sifat maupun jenisnya. Oleh karena itu, sudah tentu tidak setiap perubahan dalam diri seseorang merupakan perubahan dalam arti belajar. Maksudnya perubahan yang terjadi dalam aspek-aspek kematangan, pertumbuhan, dan perkembangan tidak termasuk perubahan dalam pengertian belajar.

Adapun ciri-ciri perubahan tingkah laku dalam pengertian belajar menurut Slameto (2003b: 3) yaitu: (1) perubahan terjadi secara sadar; (2) perubahan dalam belajar bersifat kontinu dan fungsional; (3) perubahan dalam belajar bersifat positif dan aktif; (4) perubahan dalam belajar bukan bersifat sementara; (5) perubahan dalam belajar bertujuan atau terarah; (6) perubahan mencakup seluruh aspek tingkah laku.

Sanjaya (2006: 242) mengatakan pembelajaran kooperatif merupakan model pembelajaran dengan menggunakan sistem pengelompokan/tim kecil, yaitu antara empat sampai enam orang yang mempunyai latar belakang kemampuan akademik, jenis kelamin, ras, atau suku yang berbeda (heterogen). Model pembelajaran kooperatif muncul dari konsep bahwa siswa akan lebih mudah menemukan dan memahami konsep yang sulit jika mereka saling berdiskusi dengan temannya. Konsep tersebut menurut Slavin (2008a: 2) In cooperative classrooms, students are expected to help each other, to discuss and argue with each other, to asses each other's current knowledge artinya di (dalam) kelas kerjasama, para siswa diharapkan untuk tolong menolong, untuk mendiskusikan dan membantah satu sama lain, untuk menilai pengetahuan satu sama lain. Siswa secara rutin bekerja dalam kelompok untuk saling membantu memecahkan masalah-masalah yang kompleks. Jadi, hakikat sosial dan penggunaan kelompok sejawat menjadi aspek utama dalam model pembelajaran kooperatif. Tujuan dibentuknya kelompok tersebut adalah untuk memberikan kesempatan kepada semua siswa untuk dapat terlibat secara aktif dalam proses berpikir dan kegiatan belajar. Selama bekerja dalam kelompok, tugas anggota kelompok adalah mencapai ketuntasan materi yang 
disajikan oleh guru, dan saling membantu teman sekelompoknya untuk mencapai ketuntasan belajar.

Model pembelajaran kooperatif metode Team Assisted Individualization merupakan bentuk model pembelajaran kooperatif yang menggabungkan sistem belajar kooperatif (kelompok) dengan belajar individual. Metode Team Assisted Individualization sama dengan metode Student Team Achievement Division (STAD) dan metode Teams Games Tournament (TGT) yang menggunakan kelompok-kelompok kecil yang heterogen dan memberi sertifikat untuk tim dengan kinerja yang terbaik. Namun metode STAD dan metode TGT menggunakan pola pengajaran tunggal untuk satu kelas, sementara metode Team Assisted Individualization menggabungkan model pembelajaran kooperatif dengan pengajaran yang individual.

Metode Team Assisted Individualization dirancang untuk memuaskan kriteria berikut ini untuk menyelesaikan masalah-masalah teoritis dan praktis dari sistem pengajaran individual menurut Slavin (2008b: 190-191) yaitu: (1) dapat meminimalisir keterlibatan guru dalam pemeriksaan dan pengelolaan rutin; (2) guru setidaknya akan menghabiskan separuh dari waktunya untuk mengajar kelompok-kelompok kecil; (3) operasional program tersebut akan sedemikian sederhananya sehingga para siswa pada tingkat tiga dapat melakukannya; (4) para siswa akan termotivasi untuk mempelajari materi-materi yang diberikan dengan cepat dan akurat, dan tidak akan bisa berbuat curang atau menemukan jalan pintas; (5) tersedianya banyak cara pengecekan penguasaan supaya para siswa dapat menghemat waktu dalam mempelajari kembali materi yang sudah mereka kuasai atau menghadapai kesulitan serius yang membutuhkan bantuan seorang guru; (6) para siswa akan dapat melakukan pengecekan satu sama lain, sekalipun bila siswa yang mengecek kemampuannya ada di bawah siswa yang dicek dalam rangkaian pengajaran, dan prosedur pengecekan akan cukup sederhana dan tidak mengganggu si pengecek; (7) programnya mudah dipelajari baik oleh guru maupun siswa, tidak mahal dan fleksibel; (8) dengan membuat para siswa bekerja dalam kelompokkelompok kooperatif yang heterogen, program ini akan membangun kondisi untuk terbentuknya sikap-sikap positif terhadap siswa-siswa yang cacat secara akademik dan diantara para siswa dari latar belakang ras atau eknik yang berbeda.

Metode Team Assisted Individualization tidak seperti model pembelajaran kooperatif yang lain, metode Team Assisted Individualization tergantung pada serangkaian materi pembelajaran yang khas dan mempunyai petunjuk pelaksanaan sendiri. Menurut Slavin (2008c: 195-200) metode Team Assisted Individualization merupakan bentuk model pembelajaran kooperatif yang terdiri dari delapan komponen yaitu:

1. Teams

Kelompok yang dibentuk beranggotakan empat sampai enam siswa. Kelompok tersebut merupakan kelompok heterogen yang mewakili hasil-hasil akademis dalam kelas, jenis kelamin, dan ras atau etnis. Tujuan dibentuknya kelompok adalah untuk memastikan bahwa semua kelompok ikut belajar, dan lebih khusus adalah untuk mempersiapkan anggota kelompoknya dapat mengerjakan tes dengan baik.

2. Tes Penempatan

Para siswa diberikan tes pra-program dalam bidang operasi matematika pada permulaan pelaksanaan program. Mereka ditempatkan pada tingkat yang sesuai dalam program individual berdasarkan kinerja mereka dalam tes ini.

3. Materi-materi Kurikulum

Untuk sebagian besar dari pengajaran mereka, para siswa bekerja pada materi-materi kurikulum individual yang mencakup penjumlahan, perkalian, pembagian, perpangkatan, operasi angka pecahan, desimal, rasio, persen, statistika, dan aljabar.

4. Belajar Kelompok

Siswa belajar dalam kelompok-kelompok kecil yang sudah ditetapkan untuk menyelesaikan suatu permasalahan. Dalam pembelajaran ini masing-masing siswa dalam 
kelompok berusaha membantu temannya. Jika ada anggota kelompok yang mendapatkan kesulitan, maka disarankan untuk meminta bantuan dalam kelompok sebelum meminta bantuan kepada guru.

5. Skor Tim dan Rekognisi Tim

Di akhir tiap minggu, guru menghitung skor kelompok. Skor ini didasarkan pada jumlah tugas-tugas yang diberikan, tes, dan keaktifan masing-masing kelompok. Kriteria yang tinggi dibuat untuk kelompok super, menengah untuk kelompok hebat, dan minimum untuk kelompok baik. Kelompok-kelompok yang memenuhi kriteria kelompok super atau kelompok hebat akan menerima reward.

6. Kelompok Pengajaran

Siswa yang telah mampu menguasai materi lebih dulu bertanggung jawab untuk menerangkan materi tersebut kepada anggota kelompoknya yang belum menguasai, sehingga akan diperoleh keberhasilan kelompok.

7. Tes Fakta

Seminggu dua kali, para siswa diminta mengerjakan tes-tes fakta selama beberapa menit. Para siswa tersebut diberikan lembar-lembar fakta untuk dipelajari di rumah untuk persiapan menghadapi tes-tes ini.

8. Unit Seluruh Kelas

Pada akhir tiap minggu, guru menghentikan program individual dan menghabiskan waktu satu minggu mengajari seluruh kelas kemampuan, serangkaian latihan, dan strategi penyelesaian masalah.

Seorang siswa hendaknya perlu memiliki ketangkasan atau keterampilan dalam sesuatu, misalnya dalam mengerjakan suatu soal dengan cepat dan tepat. Pada proses belajar mengajar perlu diadakan latihan untuk menguasai keterampilan. Salah satu metode untuk memenuhi tuntutan tersebut dalam proses pembelajaran adalah metode drill atau disebut juga metode latihan. Menurut Roestiyah (2012a: 125) tentang metode drill ialah suatu teknik yang dapat diartikan sebagai suatu cara mengajar dimana siswa melaksanakan kegiatan-kegiatan latihan, agar siswa memiliki ketangkasan atau keterampilan yang lebih tinggi dari apa yang dipelajari. Latihan yang bersifat praktis, mudah dilakukan oleh siswa, serta teratur melaksanakannya dapat membina siswa dalam meningkatkan penguasaan keterampilan tersebut, bahkan mungkin siswa dapat memiliki ketangkasan yang lebih sempurna dari yang diharapkan. Hal ini dapat menunjang siswa lebih berprestasi dalam bidang tertentu, misalnya juara dalam olimpiade matematika, fisika dan lainnya.

Menurut Sutarmiyati (2016: 46) metode drill adalah suatu metode mengajar dimana siswa diajak sering melakukan latihan. Dengan sering latihan siswa dapat memperoleh kecakapan motoris seperti menulis, menghitung dan menghafalkan huruf. Melalui metode ini siswa juga dapat memperoleh kecakapan mental seperti dalam penjumlahan dan perkalian. Selain itu metode latihan juga dapat membentuk kebiasaan dan menambah ketepatan, meningkatkan prestasi belajar dalam menjumlah dan mengalikan bilangan.

Metode mengajar drill menurut Roestiyah (2012b: 125) biasanya digunakan untuk tujuan agar siswa: (1) memiliki keterampilan motoris/gerak; (2) mengembangkan kecakapan intelek; (3) memiliki kemampuan menghubungkan antara sesuatu keadaan dengan hal lain. Dalam hal ini siswa memiliki keterampilan motoris/gerak seperti menghafal rumus, menulis, menghafalkan kata-kata, menggunakan suatu benda atau alat, melakukan gerakan dalam olah raga tertentu.

Ada beberapa kelebihan metode drill sebagaimana yang diungkapkan oleh Djamarah dan Zain (2013: 96) sebagai berikut: (1) untuk memperoleh kecakapan motoris, seperti menulis dan melafalkan huruf; (2) untuk memperoleh kecakapan mental seperti dalam perkalian, penjumlahan, pengurangan, pembagian, dan sebagainya; (3) untuk memperoleh kecakapan 
dalam bentuk asosiasi yang dibuat seperti membaca peta, penggunaan simbol dan sebagainya; (4) pembentukan kebiasaan yang dilakukan dan menambah ketepatan serta kecepatan; (5) pemanfaatan kebiasaan-kebiasan yang tidak memerlukan konsentrasi dalam pelaksanaannya; (6) pembentukan kebiasaan membuat gerakan-gerakan yang kompleks menjadi lebih otomatis.

Kelemahan metode drill adalah: (1) dapat menghambat bakat dan inisiatif murid, karena konsep dan prosedur telah didapat sebelumnya dari penjelasan guru; (2) melakukan latihan yang secara berulang-ulang merupakan hal yang monoton dan mudah membosankan; (3) dapat membentuk kebiasaan yang kaku, karena murid lebih banyak ditujukan untuk mendapatkan kecakapan memberikan respon secara otomatis, tanpa menggunakan intelegensi; (4) dapat menimbulkan verbalisme karena siswa lebih banyak dilatih menghafal soal-soal dan menjawabnya secara otomatis; (5) siswa akan mendapatkan keterampilan menghafal prosedur. Hal tersebut akan membuat siswa memiliki kemampuan yang sifatnya sementara, mudah dilupakan karena siswa mengerjakan latihan bukan berdasarkan pemahaman.

\section{Metodologi Penelitian}

Metode penelitian yang digunakan pada penelitian ini adalah menggunakan metode eksperimen, karena dalam penelitian ini ada 2 kelompok yang dibandingkan, diberikan perlakuan yang berbeda tanpa mengubah komposisi kelompok tersebut. Penelitian ini dilaksanakan pada salah satu SMA Negeri di Jakarta. Pengambilan data dalam penelitian ini setelah perlakuan dilaksanakan, yaitu kelompok eksperimen dan kelompok kontrol terlebih dahulu ditentukan dengan cara acak sederhana.

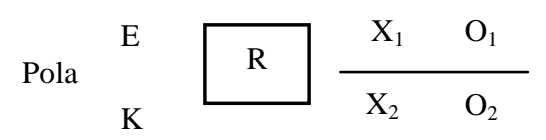

\section{Gambar 1. Desain Penelitian}

Keterangan: $\mathrm{E}$ adalah kelompok eksperimen, $\mathrm{K}$ adalah kelompok kontrol, $\mathrm{X}_{1}$ adalah perlakuan pada kelompok eksperimen, $\mathrm{X}_{2}$ adalah perlakuan pada kelompok kontrol, $\mathrm{R}$ adalah pola random, $\mathrm{O}_{1}$ adalah pemberian tes akhir (post test) pada kelompok eksperimen, $\mathrm{O}_{2}$ adalah pemberian tes akhir (post test) pada kelompok kontrol.

\section{Teknik Pengambilan Sampel}

Tabel 1. Jumlah Anggota Subjek Penelitian

\begin{tabular}{cccc}
\hline Sampel & Populasi & Subjek Penelitian & Keterangan \\
\hline Kelas XI IPA4 & 40 siswa & 30 siswa & Kelas Eksperimen \\
Kelas XI IPA3 & 40 siswa & 30 siswa & Kelas terkontrol \\
& 80 siswa & 60 siswa & \\
\hline
\end{tabular}

\section{Teknik pengumpulan data}

Data yang diambil dalam penelitian ini adalah hasil belajar matematika pada pokok bahasan turunan yang diperoleh dari tes setelah diberi perlakuan. Sebelum kedua kelompok yaitu kelompok eksperimen dengan model pembelajaran kooperatif metode Team Assisted Individualization dan kelompok kontrol dengan metode drill diberi perlakuan, terlebih dahulu dilakukan uji normalitas dengan menggunakan uji Lilliefors. Variabel bebas (X) adalah perbedaan model pembelajaran kooperatif metode Team Assisted Individualization dan metode drill; dan variabel terikat (Y) adalah hasil belajar matematika siswa. 
Hasil dan Pembahasan

Hasil rangkuman distribusi frekuensi kelas eksperimen sebagai berikut:

Tabel 2. Distribusi Frekuensi Hasil Belajar Matematika Kelas Eksperimen

\begin{tabular}{cccccc}
\hline $\begin{array}{c}\text { Kelas Interval } \\
\text { (Nilai) }\end{array}$ & $\begin{array}{c}\text { Nilai Tengah } \\
(\mathbf{X i )}\end{array}$ & Batas Nyata & Fbsolut & $\begin{array}{c}\text { Frekuensi } \\
\text { Komulatif }\end{array}$ & Relatif \\
\hline $79-82$ & 80,5 & $78,5-82,5$ & 2 & 2 & $6,667 \%$ \\
$83-86$ & 84,5 & $82,5-86,5$ & 3 & 5 & $10,000 \%$ \\
$87-90$ & 88,5 & $86,5-90,5$ & 4 & 9 & $13,333 \%$ \\
$91-94$ & 92,5 & $90,5-94,5$ & 8 & 17 & $26,667 \%$ \\
$95-98$ & 96,5 & $94,5-98,5$ & 7 & 24 & $23,333 \%$ \\
$99-102$ & 100,5 & $98,5-102,5$ & 6 & 30 & $20,000 \%$ \\
& Jumlah & & 30 & & $100 \%$ \\
\hline
\end{tabular}

Dari tabel 2 terlihat bahwa frekuensi tertinggi berada pada nilai dari 90,5 sampai 94,5 adalah 8. Dari data diperoleh nilai dari 79 sampai 102 dengan median 93,500 dan modus 93,700; rata-rata 92,233; simpangan baku 6,268.

Hasil rangkuman distribusi frekuensi kelas kontrol sebagai berikut:

Tabel 3. Distribusi Frekuensi Hasil Belajar Matematika Kelas Kontrol

\begin{tabular}{cccccc}
\hline $\begin{array}{c}\text { Kelas Interval } \\
\text { (Nilai) }\end{array}$ & $\begin{array}{c}\text { Nilai Tengah } \\
\text { (Xi) }\end{array}$ & Batas Nyata & Absolut & $\begin{array}{c}\text { Frekuensi } \\
\text { Komulatif }\end{array}$ & Relatif \\
\hline $63-68$ & 65,5 & $62,5-68,5$ & 2 & 2 & $6,667 \%$ \\
$69-74$ & 71,5 & $68,5-74,5$ & 3 & 5 & $10,000 \%$ \\
$75-80$ & 77,5 & $74,5-80,5$ & 9 & 14 & $30,000 \%$ \\
$81-86$ & 83,5 & $80,5-86,5$ & 7 & 21 & $23,333 \%$ \\
$87-92$ & 89,5 & $86,5-92,5$ & 6 & 27 & $20,000 \%$ \\
$93-98$ & 95,5 & $92,5-98,5$ & 3 & 30 & $10,000 \%$ \\
& Jumlah & & 30 & & $100 \%$ \\
\hline
\end{tabular}

Dari tabel 3 terlihat bahwa frekuensi tertinggi berada pada nilai dari 74,5 sampai 80,5 adalah 9. Dari data diperoleh nilai dari 63 sampai 98 dengan median 81,358 dan modus 79,000; rata-rata 81,967; simpangan baku 8,240.

Pengujian hipotesis hasil belajar matematika siswa bertujuan untuk mengetahui ada atau tidak adanya perbedaan hasil belajar matematika siswa dengan model pembelajaran kooperatif metode Team Assisted Individualization dan metode drill.

\section{Uji Normalitas}

Hasil rangkuman uji normalitas hasil belajar matematika siswa disajikan pada tabel 4 berikut.

Tabel 4. Hasil Uji Normalitas Kelas Eksperimen dan Kelas Kontrol

\begin{tabular}{ccccc}
\hline Variabel & $\mathbf{N}$ & $\mathbf{L}_{\text {hitung }}\left(\mathbf{L}_{\mathbf{0}}\right)$ & $\mathbf{L}_{\text {tabel }}$ & Simpulan \\
\hline $\mathrm{X}_{1}$ & 30 & 0,1075 & 0,161 & Data Berdistribusi Normal \\
$\mathrm{X}_{2}$ & 30 & 0,1483 & 0,161 & Data Berdistribusi Normal \\
\hline
\end{tabular}


Tabel 4 di atas menunjukkan bahwa hasil perhitungan skor hasil belajar matematika siswa kelas eksperimen dan kelas kontrol memiliki nilai signifikan yang lebih besar dari $\alpha=0,05$. Maka dapat disimpulkan $\mathrm{H}_{0}$ diterima, artinya secara signifikan sebaran rata skor hasil belajar matematika siswa pada kelas eksperimen dan kelas kontrol berdistribusi normal.

\section{Uji Homogenitas}

Uji homogenitas dua varian antara kelas eksperimen dan kelas kontrol dilakukan dengan menggunakan uji fisher. Pengujian homogenitas di dapat $F_{\text {hitung }}=0,579$ dan $F_{\text {tabel }}(0,95)=$ 0,$5374 ; F_{\text {tabel }(0,05)}=1,8608$ pada taraf signifikasi $\alpha=0,05$; derajat kebebasan pembilang 29 dan derajat kebebasan penyebut 29. Karena $F_{0,95(29,29)}<F_{\text {hitung }}<F_{0,05(29,29)}$ atau $0,5374<0,579<1,8608$ dapat disimpulkan kelas eksperimen dan kelas kontrol mempunyai varians yang sama atau homogen.

\section{Hasil Pengujian Hipotesis}

Hipotesis yang diajukan menggunakan uji t-tes. Dari perhitungan diperoleh nilai $t_{\text {hitung }}=$ 5,432 dan $t_{\text {tabel }}=2,002$ dengan taraf signifikansi $\alpha=0,05$ dan derajat kebebasan $(\mathrm{dk})=$ 58 . Terlihat bahwa hasil yang diperoleh t-hitung lebih besar dari t-tabel $\left(t_{\text {hitung }}=5,432>\right.$ $\left.2,002=t_{\text {tabel }}\right)$ menyebabkan $\mathrm{H}_{0}$ yang menyatakan tidak ada perbedaan hasil belajar matematika siswa dengan model pembelajaran kooperatif metode Team Assisted Individualization dan metode drill ditolak, sedangkan $\mathrm{H}_{1}$ diterima. Diterimanya $\mathrm{H}_{1}$ dapat disimpulkan bahwa terdapat perbedaan hasil belajar matematika siswa dengan model pembelajaran kooperatif metode Team Assisted Individualization dan metode drill.

Berdasarkan hasil penelitian yang telah dikemukakan di atas, dibandingkan dengan metode drill, model pembelajaran kooperatif metode Team Assisted Individualization menunjukkan bahwa metode ini berperan dalam meningkatkan hasil belajar matematika siswa. Setelah dilakukan pre-test, pembelajaran dilaksanakan pada kedua kelas. Pembelajaran dilaksanakan sebanyak 9 kali pertemuan dengan topik materi turunan. Kelas eksperimen melaksanakan dengan model pembelajaran kooperatif metode Team Assisted Individualization dan kelas kontrol melaksanakan pembelajaran dengan metode drill. Pada proses model pembelajaran kooperatif metode Team Assisted Individualization siswa dibagi menjadi 5 kelompok. Setiap kelompok dipilih ketua untuk menjadi tutor sebaya dalam kelompok tersebut. Pada proses pembelajaran guru memberikan persoalan yang harus diselesaikan oleh siswa. Apabila siswa tersebut belum memahami persoalan maka ketua wajib memberi bantuan untuk mengatasi persoalan tersebut, dan apabila ketua tidak sanggup maka guru berperan sebagai fasilitator.

Fakta pada pertemuan pertama siswa sulit untuk menjalankan proses model pembelajaran kooperatif metode Team Assisted Individualization. Namun, dengan seiring waktu dan guru yang berperan sebagai fasilitator maka pertemuan-pertemuan selanjutnya dapat dijalani lebih mudah, sehingga model pembelajaran ini tercapai.

Kegiatan diskusi kelompok pada penelitian ini siswa bisa saling berinteraksi dalam menyampaikan ide-ide mereka, menanggapi dan menjawab pertanyaan dari kelompok lain sehingga dapat memberikan pengaruh positif terhadap hasil belajar matematika siswa. Pada diskusi kelompok, ketua bertanggung jawab untuk menerangkan materi tersebut kepada anggota kelompoknya yang belum menguasai, sehingga akan diperoleh keberhasilan kelompok. Setelah seluruh kelompok selesai melakukan diskusi, maka guru meminta salah satu perwakilan kelompok untuk menyampaikan hasil diskusi mereka dan kelompok lain diberikan kesempatan untuk bertanya atau menambahkan hasil presentasi yang disajikan oleh kelompok penyaji. Dengan adanya kegiatan diskusi ini, menyebabkan adanya peningkatan hasil belajar matematika siswa. Melalui kegiatan diskusi ini siswa lebih siap menjelaskan pemahaman konsep yang mereka pahami di depan kelas serta menjawab 
pertanyaan dari kelompok lain pada saat terjadinya diskusi kelas, sehingga dengan demikian dapat meningkatkan hasil belajar matematika siswa.

Setiap kali pertemuan, diadakan tes fakta kepada siswa untuk melihat peningkatan hasil belajar mereka. Tes fakta ini dilakukan sekitar 10 menit dengan 2 buah soal. Pada pertemuan pertama hingga pertemuan kelima terdapat peningkatan hasil belajar siswa. Namun, pertemuan keenam terdapat penurunan hasil belajar siswa, hal ini disebabkan materi pembelajaran yang cukup sulit. Sehingga guru memberikan latihan soal yang lebih intensif kepada siswa.

Penelitian yang berkaitan dengan model pembelajaran kooperatif metode Team Assisted Individualization di antaranya diteliti oleh Karim (2015: 58) tentang kemampuan pemecahan masalah matematis siswa dengan menerapkan model pembelajaran kooperatif tipe Team Assisted Individualization. Hasil penelitiannya menunjukkan bahwa model pembelajaran kooperatif tipe Team Assisted Individualization dapat melatih kemampuan pemecahan masalah matematis siswa. Hal ini dapat dilihat dari hasil post test selama enam kali pertemuan dan hasil evaluasi akhir pada pertemuan ketujuh berada pada kualifikasi baik. Relevansi dengan penelitian ini adalah peneliti juga lebih menekankan pada hasil belajar siswa dengan menerapkan model pembelajaran kooperatif metode Team Assisted Individualization. Namun terdapat perbedaan, peneliti hanya menitik beratkan pada hasil belajar siswa tanpa melihat kemampuan pemecahan masalah matematis siswa.

Penelitian lain yang meneliti tentang model pembelajaran kooperatif metode Team Assisted Individualization yaitu Susilawati (2015: 323) tentang eksperimentasi model pembelajaran kooperatif tipe Team Assisted Individualization dengan Guided Note Taking (GNT). Hasil penelitiannya menunjukkan bahwa siswa yang menerapkan model pembelajaran kooperatif tipe Team Assisted Individualization dengan GNT menghasilkan prestasi belajar yang lebih baik dibandingkan model pembelajaran kooperatif tipe Team Assisted Individualization dan model pembelajaran konvensional. Berkaitan dengan penelitian yang telah dilakukan, peneliti juga lebih menekankan hasil belajar siswa dengan menerapkan model pembelajaran kooperatif metode Team Assisted Individualization. Adapun hasil penelitian yang diperoleh bahwa hasil belajar matematika siswa yang menerapkan model pembelajaran kooperatif metode Team Assisted Individualization lebih baik daripada siswa yang menerapkan metode drill.

\section{Simpulan dan Saran \\ Simpulan}

Berdasarkan hasil analisis data yang telah dilakukan, maka dapat disimpulkan: hasil belajar matematika siswa kelas eksperimen (yang menggunakan model pembelajaran kooperatif metode Team Assisted Individualization) dengan rata-rata 92,233 dan simpangan baku 6,268. Hasil belajar matematika siswa kelas kontrol (yang menggunakan metode drill) dengan ratarata 81,967 dan simpangan baku 8,240. Pada tingkat signifikasi $\alpha=0,05$ terlihat bahwa $t_{\text {hitung }}=5,432$ dan $t_{\text {tabel }}=2,002$ sehingga $t_{\text {hitung }}$ lebih besar dari pada $t_{\text {tabel }}$, maka hipotesis alternatifnya di terima $\left(\mathrm{H}_{1}\right)$. Artinya terdapat perbedaan hasil belajar matematika siswa dengan model pembelajaran kooperatif metode Team Assisted Individualization dan metode drill.

Rata-rata hasil belajar matematika siswa yang menggunakan model pembelajaran kooperatif metode Team Assisted Individualization lebih tinggi dari rata-rata hasil belajar matematika siswa yang menggunakan metode drill. Hal ini menunjukan bahwa pembelajaran matematika menggunakan model pembelajaran kooperatif metode Team Assisted Individualization dapat meningkatkan hasil belajar matematika siswa pada salah satu SMA Negeri di Jakarta dengan 
pokok bahasan turunan. Pembelajaran menggunakan model pembelajaran kooperatif metode Team Assisted Individualization dapat menjadi alternatif pembelajaran matematika, karena model pembelajaran ini menjadikan siswa lebih aktif dalam kegiatan pembelajaran.

\section{Saran}

Penulis menyadari penelitian ini masih jauh dari sempurna, karena keterbatasan ilmu yang dimiliki penulis serta masih banyak faktor lain yang dapat menentukan berhasil atau tidaknya penelitian ini. Berdasarkan hasil penelitian yang diperoleh, maka dapat disarankan sebagai berikut:

1. Guru hendaknya menerapkan metode pembelajaran yang sesuai dengan pokok bahasan yang diberikan agar tercipta proses belajar mengajar yang efektif dan efesien.

2. Guru sebelum mengajarkan menggunakan metode Team Assisted Individualization, siswa terlebih dahulu harus memahami konsep-konsep pokok bahasan. Para guru matematika perlu meningkatkan kemampuan dan keterampilan dalam bentuk penguasaan ragam model pembelajaran dan metode membangkitkan minat dan perhatian siswa dalam pelajaran matematika agar belajar matematika menjadi menarik dan menyenangkan.

3. Guru hendaknya memperhatikan pengelolaan kelas pada saat kegiatan belajar mengajar berlangsung sehingga setiap siswa dapat ikut aktif dalam belajar.

4. Guru harus mempersiapkan materi dan soal-soal latihan yang dibutuhkan dalam kegiatan pembelajaran.

5. Siswa diharapkan untuk mengikuti langkah-langkah dalam proses pembelajaran baik pada model pembelajaran kooperatif metode Team Assisted Individualization maupun metode drill, agar kegiatan belajar mengajar dapat berjalan dengan baik sehingga tercapai hasil yang optimal. Dan apabila mendapatkan suatu masalah dalam matematika baiknya diselesaikan dengan berdiskusi bersama teman-temannya dan guru.

6. Orang tua diharapkan selalu memperhatikan kemajuan anak-anaknya dan membantu pada saat anak-anaknya mendapatkan kesulitan pelajaran pada saat di rumah serta tidak lupa selalu memberikan motivasi-motivasi yang dapat meningkatkan kualitas belajar mereka.

7. Mengingat hasil penelitian ini masih sangat sederhana, apa yang didapat dari hasil penelitian ini bukan merupakan hasil akhir, tentu segala keterbatasan yang ada dalam penelitian ini dapat dijadikan bahan referensi untuk penelitian lebih lanjut, dengan memperhatikan kemungkinan adanya variabel-variabel lain yang turut mempengaruhi pembelajaran.

\section{Daftar Pustaka}

Departemen Pendidikan Nasional. (2003). Undang-undang Republik Indonesia Nomor 20 Tahun 2003 tentang Sistem Pendidikan Nasional. Depdiknas: Jakarta

Djamarah, S. B., \& Zain, A. (2013). Strategi Belajar Mengajar. Jakarta: Rineka Cipta.

Karim. (2016). Penerapan Model Pembelajaran Kooperatif Tipe Team Assisted Individualization (TAI) untuk Melatih Kemampuan Pemecahan Masalah Matematis Siswa SMA. Jurnal Pendidikan Matematika, Vol. 4 No. 1 Tahun 2016. 58-67.

Roestiyah, N. K. (2012). Strategi Belajar Mengajar. Jakarta: Rineka Cipta.

Sanjaya, Wina. (2005). Pembelajaran dalam Implementasi Kurikulum Berbasis Kompetensi. Jakarta: Kencana Prenada Media Group.

Sanjaya, Wina. (2006). Strategi Pembelajaran Berorientasi Standar Proses Pendidikan. Jakarta: Kencana Prenada Media Group.

Slameto. (2003). Belajar dan Faktor-Faktor yang Mempengaruhinya. Jakarta: Rineka Cipta.

Slavin, E Robert. (2008) Cooperative Learning: Teori, Riset, dan Praktik. Bandung: Nusa Media. 
Suprijono, Agus. (2009). Cooperatif Learning Teori \& Aplikasi Paikem. Yogyakarta: Pustaka Belajar.

Susilawati, Dyah. (2015). Eksperimentasi Model Pembelajaran Kooperatif Tipe Team Assisted Individualization (TAI) dengan Guided Note Taking (GNT) pada Materi Bangun Ruang Ditinjau dari Aktivitas Belajar Siswa Kelas VIII SMP Negeri SeKabupaten Klaten Tahun Pelajaran 2013/2014. Jurnal Elektronik Pembelajaran Matematika, Vol. 3 No. 3 Tahun 2015. 313-325.

Sutarmiyati. (2016). Penggunaan Metode Drill pada Materi Ajar Penjumlahan Bilangan Pecahan. Jurnal Penelitian Pendidikan Indonesia, Vol. 1 No. 1 Tahun 2016. 45-50. 